\title{
Natural evaluation of landscape in urban area comprising Bielański Forest nature reserve and surroundings, Warsaw, Poland. Directions for landscape protection and planning
}

\author{
BEATA FORNAL-PIENIAK, BARBARA ŻARSKA, \\ EWA ZARAŚ-JANUSZKIEWICZ \\ Faculty of Horticulture, Biotechnology and Landscape Architecture, Warsaw University of Life \\ Sciences - SGGW, Poland
}

\begin{abstract}
Natural evaluation of landscape in urban area comprising Bielański Forest nature reserve and surroundings, Warsaw, Poland. Directions for landscape protection and planning. Problems of maintaining remnants of natural ecosystems in urbanized areas, planning of systems of natural areas in cities and ways of natural evaluation for these purposes, in order to improve environmental conditions for inhabitants, are very current. The aim of the paper is the presentation of methodical approach to natural evaluation of landscape and formulating recommended guidelines for landscape protection and planning in the urban study area including the Bielański Forest nature reserve and its surroundings. The presented method of landscape evaluation consists on: division of the study area into spatial-landscape units characterized with relatively similar type of landscape, analyses in units' areas and external preconditions, selection of suitable criteria of natural evaluation determining the way of estimation - the range of points awarded in each criterion (points bonitation) and interpretation of results. The guidelines for landscape protection and planning have been formulated, among others maintaining and improving of three external ecological corridors.
\end{abstract}

Key words: landscape planning, natural evaluation of landscape, remnants of natural ecosystems, urbanized area, natural system of areas

\section{INTRODUCTION}

Landscape evaluation and planning have gained greater range since the European Landscape Convention - ELC (2000) came into force (Polish Journal of Laws 2006 No 14, item 98). According to ELC, the landscape inventory and evaluation are indicated and precede recommendation to protection and planning. The background for this convention is really special. In the face of environmental threats, there is a need to assure suitable environmental conditions for human population, including adaptation to climate warming, with special regard to urbanized areas, where environmental problems accumulate (Commission of European Parliament COM/2013/216). The strategic world action, considering sustainable development and adaptation to climate warming, is transfer to green economy (UNEP 2011), comprising creation of green infrastructure in areas (GI) (Benedict and McMachon 2006, Commission of European Parliament COM/2013/0249 Communication from the Commision COM/2011/0244). For 
these reasons, the interest of researchers has recently, in last decades, increased in such issues, including landscape evaluation as a base for rational planning, with special regard on cities as especially threatened areas (Moss and Nickling 1980, Brunetta and Voghera 2008, Hessburg et al. 2013, Zina and McShane 2018).

Maintenance and proper management of towns and their systems of green areas, including legally protected sites, give a real chance to keep relatively high biological diversity in cities (Shanahan et al. 2011, Threlfall et al. 2016). Creation of systems of biologically active terrains (hierarchical and continuous layouts) in cities has been quickly developed since 1990s (Szulczewska and Kaftan (Ed.) 1996, Jim 2004, Bryant 2006, Yu Ting and Makoto 2017), recently also known as creating of green infrastructure. At present, you can no longer afford city planning without a natural system of areas and pro-ecological solutions. Many research give evidence that increase of green areas / green elements in total urbanized area influence the improvement of climatic conditions, as lowering temperature and increasing the ability to collect rainwater, to a large extent (Gill et al. 2007, Emanuel and Loconsole 2015). Natural evaluation of landscape is the constant element in methodical approach to indicate natural system of an area. It gives the evidence of terrain natural values and enables formulating directions to functions and development. In natural evaluation of landscape the most important are: criteria of assessment (measures of various natural values) and the way of assessment (ex. bonitation - points). Selection of criteria depends on the detailed purpose of elaboration (Żarska 2001).
The mostly used criteria, in natural evaluation, are: variety of terrain relief, occurrence of distinctive forms of terrain, occurrence of surface water, naturalness of vegetation cover, species richness, occurrence of rare and protected species, variety of ecosystems, area occupied by ecosystems of natural and semi-natural ecosystems (Alexandrowicz et al. 1992, Gacka-Grzesikiewicz et al. 1994, Żarska 2001).

In the field of architecture / landscape architecture the basic method of landscape evaluation is JARK-WARK (eng. ALU-ALI) method elaborated in Cracow school of architecture under Prof. Janusz Bogdanowski's direction in 1990s (Myga-Piątek 2007). Authors of this method have tried to combine all strata of landscape: assessment of natural environment with assessment of cultural environment (landscape) in connection to visual aspects - and to enrich architectural studies in features coming from genesis and natural specificity. This is the method of architectural-landscape units (ALU) - addressed to planning scales and method of architectural-landscape interiors (ALI) - for architectonic scales. The JARK-WARK method involves such stages: determining of landscape resources (inventory of the contents - natural and cultural), evaluation of phenomenon, contents and forms (positive and negative aspects), formulating of guidelines for landscape planning. Myga-Piątek (2007) has proposed following criteria for cultural landscape evaluation: antiquity, historicity, aesthetics, original material, composition, uniqueness, typicality, distinctness, contents and form, emotional and integration value, usability and economic value. 
The aim of the paper is the presentation of methodical approach to natural evaluation of urban landscape including remnants of nature - in the study area comprising the Bielański Forest nature reserve and its vicinity in Warsaw, Poland. On this base, recommended changes in spatial management and landscape have been presented regarding protection of natural resources and good environmental features beneficial for city residents.

\section{STUDY AREA}

\section{AND METHODOLOGY}

The study area includes the Bielański Forest nature reserve and its surroundings in the Bielany city district in northern Warsaw and covers $3.85 \mathrm{~km}^{2}$ (Fig. 1). It is localised in the Vistula river valley, in the east bounded with this river bed. The nature reserve (set up in 1973) covers $1.3 \mathrm{~km}^{2}$ (130.35 ha; it is $1 / 3$ of the study area, inside localisation). The Bielański Forest is also under the protection of the Nature 2000 Area PLH 140041 in order to protect important European forest habitats and species. This reserve is the only remnant of the former Mazovia Primeval Forest, which is witnessed by some 400-year-old oak trees, absorbed by big city development. The area covered by this forest has very diverse relief of terrain: high and steep slopes of escarpments and four terraces of the Vistula valley. The Vistula river (adjacent to the study area) and area on flood terraces between embankments is also protected as the Nature 2000 Area for birds PLB 140004 "The Middle Vistula River Valley".

For the need of inventory and analyses, the study area has been divided into spatial-landscape unites characterized with relatively one type of landscape. This division has been made on the base of main criteria: relief of the terrain and coverage of the terrain.

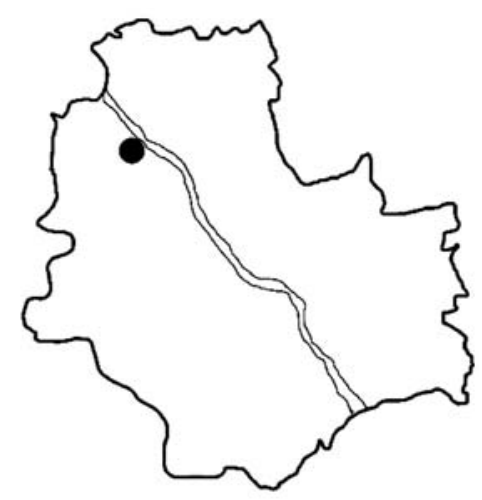

FIGURE 1. Localization of the study area including the Bielański Forest nature reserve within Warsaw borders. The Vistula river (marked with double line) is the landscape-ecological axis of the city and Bielański Forest is localized in the Vistula valley on flood and upper terraces (original)

The landscape structure has been analysed in three important aspects: qualitative analysis, quantitative analysis and spatial analysis (Żarska et al. 2014). The qualitative analysis concerned elements building the landscape of elaborated area, e.g. forest ecosystems, water, arable lands, meadows, built-up areas etc. The quantitative analysis showed the share of every type of structural elements in total area. The diverse types of coverage have been calculated and estimated with the help of the topographic map (1:10 000) and field research giving regard to image of spatial layout of landscape elements. In addition to the material collected during the field research, satellite pictures of 
the area were very helpful (Geoportal. pl, Geosevis.pl).

Basing on the spatial-landscape units division, a natural evaluation of landscape has been conducted in the next stage of the work. In order to assess the ecological value of the landscape, a list with nine relevant criteria and the system of estimation (bonitation scores) were assumed (Table 1). As obtained from the list, a theoretical maximum value of 22 points could be achieved.
After scoring every unit, four categories of natural value were defined. Depending on achieved sum of points, every unit was assigned to relevant category of natural value.

The last stage of the work was formulating of directions for landscape protection and planning in the study area, with special regarding enrichment of ecological structure of landscape and ecological connectivity.

TABLE 1. Natural evaluation of landscape in the study area: criteria of assessment and bonitation points (original)

\begin{tabular}{|c|c|c|c|}
\hline $\begin{array}{l}\text { Ordinar } \\
\text { number }\end{array}$ & Main criteria & Gradation & Points \\
\hline \multirow{3}{*}{1} & \multirow{3}{*}{ diversity of terrain relief } & very diversified & 3 \\
\hline & & medium diversified & 2 \\
\hline & & low diversified & 1 \\
\hline \multirow{3}{*}{2} & \multirow{3}{*}{ occurrence of surface water } & big water courses & 3 \\
\hline & & local water courses & 2 \\
\hline & & artificial small reservoirs & 1 \\
\hline \multirow{3}{*}{3} & \multirow{3}{*}{ naturalness of vegetation } & vegetation of natural character predomination & 3 \\
\hline & & semi-natural vegetation predomination & 2 \\
\hline & & synantropical vegetation predomination & 1 \\
\hline \multirow{3}{*}{4} & \multirow{3}{*}{ species richness } & high & 3 \\
\hline & & medium & 2 \\
\hline & & low & 1 \\
\hline \multirow{3}{*}{5} & \multirow{3}{*}{ forest occurrence } & big-sized forest complexes of local scale & 3 \\
\hline & & medium forest complexes of local scale & 2 \\
\hline & & plantings of forest character & 1 \\
\hline \multirow{2}{*}{6} & \multirow{2}{*}{ grassland occurrence } & yes/occurrence & 1 \\
\hline & & no occurrence & 0 \\
\hline \multirow{2}{*}{7} & \multirow{2}{*}{ old trees } & yes/occurrence & 1 \\
\hline & & no occurrence & 0 \\
\hline \multirow{2}{*}{8} & \multirow{2}{*}{ green areas occurrence } & yes/occurrence & 1 \\
\hline & & no occurrence & 0 \\
\hline \multirow{3}{*}{9} & \multirow{3}{*}{$\begin{array}{l}\text { usefulness for function } \\
\text { of ecological corridor }\end{array}$} & high & 3 \\
\hline & & medium & 2 \\
\hline & & low & 1 \\
\hline
\end{tabular}




\section{RESULTS}

\section{Delimitation of spatial-landscape units}

The division of the study area into spatial-landscape units (Fig. 2) has been carried out for needs of inventory, analysis and landscape evaluation. A list of types of landscape (correlated well with land use) occurring in the study area was compiled (Table 2). This was performed by using the open-source geographic information system QGIS. In total, 11 various types of spatial-landscape units have been distinguished in the study area, in all - types and subtypes: 28 units.

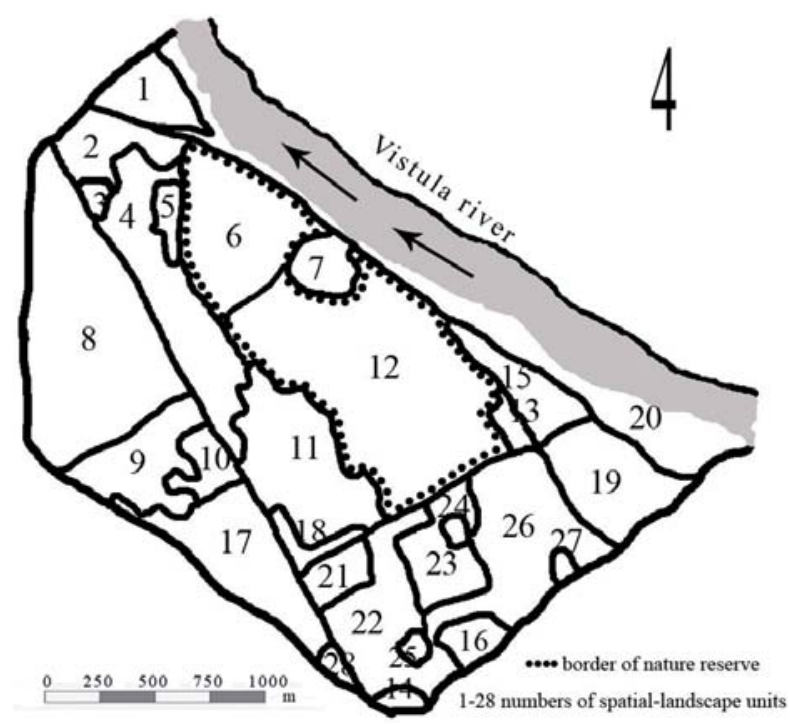

FIGURE 2. Scheme of division into spatial-landscape units in the study area: the Bielański Forest nature reserve and vicinity

TABLE 2. Types and subtypes of landscape occurring in spatial-landscape units in the study area (original)

\begin{tabular}{|c|c|c|c|}
\hline $\begin{array}{l}\text { Main type of landscape in } \\
\text { spatial-landscape unit }\end{array}$ & $\begin{array}{l}\text { Subtype of landscape } \\
\text { in unit } \\
\end{array}$ & $\begin{array}{c}\text { Number of } \\
\text { unit }\end{array}$ & Characteristics \\
\hline \multirow{3}{*}{$\begin{array}{l}\text { Forest predomination / } \\
\text { / surface water }\end{array}$} & $\begin{array}{l}\text { oak-hornbeam forest } \\
\text { predomination, } \\
\text { local streams }\end{array}$ & $4,6,12$ & $\begin{array}{l}\text { oak hornbeam forest as remnant of Ma- } \\
\text { zovian Primeval Forest located in nature } \\
\text { reserve (units } 6 \text { and 12), and in buffer zone } \\
\text { (unit 4) } \\
\text { local stream - Bielański Potok running } \\
\text { through the middle of Bielański Forest } \\
\text { (units } 4 \text { and 12) }\end{array}$ \\
\hline & $\begin{array}{l}\text { riparian forest predomi- } \\
\text { nation, old river bed } \\
\text { and local streams }\end{array}$ & 20 & $\begin{array}{l}\text { riparian forests with rushes and water veg- } \\
\text { etation in the Vistula river bed complex }\end{array}$ \\
\hline & $\begin{array}{l}\text { mixed pine forests } \\
\text { and local streams/water }\end{array}$ & 9 & $\begin{array}{l}\text { Linde's Forest - forest disturbed by } \\
\text { anthropogenic pressure, Pinus silvestris as } \\
\text { predominant tree species } \\
\text { local stream - Bielański Potok running } \\
\text { through the middle of Linde's Forest }\end{array}$ \\
\hline
\end{tabular}


TABLE 2. cont.

\begin{tabular}{|c|c|c|c|}
\hline $\begin{array}{l}\text { Main type of landscape in } \\
\text { spatial-landscape unit }\end{array}$ & $\begin{array}{l}\text { Subtype of landscape } \\
\text { in unit }\end{array}$ & $\begin{array}{c}\text { Number of } \\
\text { unit }\end{array}$ & Characteristics \\
\hline $\begin{array}{l}\text { Mixed vegetation, low share } \\
\text { of building }\end{array}$ & - & $14,16,25$ & $\begin{array}{l}\text { many small areas with mosaic vegeta- } \\
\text { tion (single trees, groups of trees, shrubs, } \\
\text { grasses, and synanthropic vegetation) }\end{array}$ \\
\hline Urban park & - & 19 & $\begin{array}{l}\text { park with share of natural, semi-natural } \\
\text { vegetation and surface water (green area) }\end{array}$ \\
\hline \multirow{3}{*}{ Build-up areas } & $\begin{array}{l}\text { residential blocks with } \\
\text { share of greenery }\end{array}$ & $\begin{array}{l}8,17,18 \\
22,26\end{array}$ & $\begin{array}{l}\text { residential blocks with meaning share of } \\
\text { greenery area } \\
\text { intensive built-up areas (trees, shrubs and } \\
\text { small patches of grasslands/lawns occur- } \\
\text { ring) }\end{array}$ \\
\hline & $\begin{array}{l}\text { single housing estates } \\
\text { with share of greenery }\end{array}$ & 13,23 & $\begin{array}{l}\text { areas of single housing estates with private } \\
\text { gardens and diversified composition of } \\
\text { plant species }\end{array}$ \\
\hline & $\begin{array}{l}\text { public buildings with } \\
\text { share of greenery }\end{array}$ & $\begin{array}{c}2,7,10,11 \\
21,24\end{array}$ & $\begin{array}{l}\text { public buildings in the study area including } \\
\text { hospitals (unit 10), schools and Cardinal } \\
\text { Stefan Wyszyński University (units 7, } \\
11,21 \text { and 24) and sport grounds (unit 2) } \\
\text { (most of them show a relatively high share } \\
\text { of greenery, especially those located within } \\
\text { or next to forest areas) }\end{array}$ \\
\hline \multirow{2}{*}{ Other public areas } & industrial area & 1 & $\begin{array}{l}\text { industrial area adjacent to the riparian } \\
\text { forest }\end{array}$ \\
\hline & cemetery & 3 & $\begin{array}{l}\text { the cemetery of Italian soldiers and citizens } \\
\text { killed during the World War I and II }\end{array}$ \\
\hline
\end{tabular}

\section{Natural evaluation of landscape}

Results of natural evaluation of landscape are varied (Table 3, Fig. 3). In assessment the following categories of natural values have been assumed: category A - areas/spatial-landscape units of very high naturalv alues (17-19 points), category B - areas/spatial-landscape units of high natural values (12-16 points), category $\mathrm{C}$ - areas/spatial-landscape units of medium natural values (7-11 points), category D - areas/spatial-landscape units of low natural values (5-7 points).
The forest areas, the islands in the Vistula river bed and the big public park (units 12,6 and 20) obtained the very high landscape value category. The smaller public parks and one public building area (units 4, 9, 15 and 19) received high value category. The most of built-up areas and the allotment garden areas are of medium natural value. Only two units (industrial area and one area of residential blocks) have got the lowest category of landscape value. 
TABLE 3. Point results of natural evaluation of the study area - ranking of units (original)

\begin{tabular}{|c|c|c|c|c|c|c|c|c|c|c|c|}
\hline \multirow{2}{*}{$\begin{array}{l}\text { Unit } \\
\text { number }\end{array}$} & \multicolumn{9}{|c|}{ Number of assessment criteria and points obtained } & \multirow{2}{*}{$\begin{array}{l}\text { Sum } \\
\text { of points }\end{array}$} & \multirow{2}{*}{ Point results } \\
\hline & 1 & 2 & 3 & 4 & 5 & 6 & 7 & 8 & 9 & & \\
\hline 12 & 3 & 2 & 3 & 3 & 3 & 0 & 1 & 1 & 3 & 19 & \multirow{3}{*}{$\begin{array}{l}\text { areas/spatial-landscape } \\
\text { units of very high natural } \\
\text { values }\end{array}$} \\
\hline 6 & 3 & 0 & 3 & 3 & 3 & 0 & 1 & 1 & 3 & 17 & \\
\hline 20 & 1 & 3 & 3 & 3 & 2 & 0 & 1 & 1 & 3 & 17 & \\
\hline 4 & 2 & 2 & 3 & 3 & 3 & 0 & 0 & 0 & 3 & 16 & \multirow{4}{*}{$\begin{array}{l}\text { areas/spatial-landscape } \\
\text { units of high natural } \\
\text { values }\end{array}$} \\
\hline 19 & 1 & 1 & 2 & 2 & 1 & 1 & 1 & 1 & 3 & 13 & \\
\hline 15 & 2 & 0 & 2 & 2 & 1 & 1 & 1 & 1 & 2 & 13 & \\
\hline 9 & 2 & 2 & 3 & 1 & 3 & 0 & 0 & 1 & 2 & 14 & \\
\hline 14 & 1 & 0 & 2 & 2 & 0 & 1 & 0 & 1 & 2 & 9 & \multirow{10}{*}{$\begin{array}{l}\text { areas/spatial-landscape } \\
\text { units of medium natural } \\
\text { values }\end{array}$} \\
\hline 23 & 1 & 0 & 2 & 2 & 0 & 1 & 0 & 1 & 2 & 9 & \\
\hline 5 & 1 & 0 & 2 & 2 & 0 & 1 & 0 & 0 & 2 & 8 & \\
\hline 16 & 1 & 0 & 2 & 2 & 0 & 1 & 0 & 0 & 2 & 8 & \\
\hline 25 & 1 & 0 & 2 & 2 & 0 & 1 & 0 & 0 & 2 & 8 & \\
\hline 27 & 1 & 0 & 2 & 2 & 0 & 1 & 0 & 0 & 2 & 8 & \\
\hline 28 & 1 & 0 & 2 & 2 & 0 & 1 & 0 & 0 & 2 & 8 & \\
\hline 2 & 1 & 0 & 1 & 1 & 1 & 1 & 0 & 1 & 2 & 8 & \\
\hline 10 & 1 & 1 & 2 & 1 & 1 & 0 & 0 & 1 & 1 & 8 & \\
\hline 11 & 1 & 0 & 2 & 1 & 2 & 0 & 0 & 1 & 1 & 8 & \\
\hline 7 & 1 & 0 & 1 & 1 & 0 & 1 & 0 & 0 & 1 & 6 & \multirow{11}{*}{$\begin{array}{l}\text { areas/spatial-landscape } \\
\text { units of low natural values }\end{array}$} \\
\hline 13 & 1 & 0 & 1 & 1 & 0 & 1 & 0 & 1 & 1 & 6 & \\
\hline 17 & 1 & 0 & 1 & 1 & 1 & 0 & 0 & 1 & 1 & 6 & \\
\hline 18 & 1 & 0 & 1 & 1 & 1 & 0 & 0 & 1 & 1 & 6 & \\
\hline 26 & 1 & 0 & 1 & 1 & 1 & 0 & 0 & 1 & 1 & 6 & \\
\hline 1 & 1 & 0 & 1 & 1 & 0 & 1 & 0 & 0 & 1 & 5 & \\
\hline 3 & 1 & 0 & 1 & 1 & 0 & 1 & 0 & 0 & 1 & 5 & \\
\hline 8 & 1 & 0 & 1 & 1 & 1 & 1 & 0 & 0 & 1 & 6 & \\
\hline 21 & 1 & 0 & 1 & 1 & 0 & 1 & 0 & 0 & 1 & 5 & \\
\hline 22 & 1 & 0 & 1 & 1 & 0 & 1 & 0 & 0 & 1 & 5 & \\
\hline 24 & 1 & 0 & 1 & 1 & 0 & 1 & 0 & 0 & 1 & 5 & \\
\hline
\end{tabular}

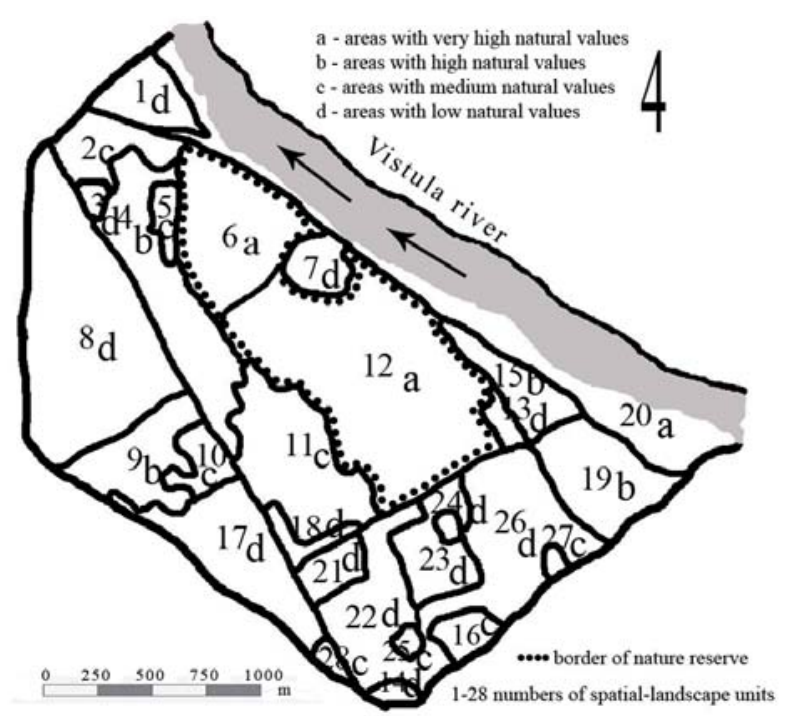

FIGURE 3. Natural evaluation of landscape in the study area: the Bielański Forest and vicinity (original) 


\section{Directions for landscape protection and planning}

Guidelines for landscape protection and planning are mainly addressed to surroundings of Bielański Forest nature reserve. Endangerments in area of nature reserve (first of all excessive movement associated with Cardinal Stefan Wyszyński University and recreation of Warsaw residents), ways of minimizing these threats and protective activities are established in the new protection plan (obligatory legal document for nature reserves in Poland; Plan ochrony... 2016).

The landscape inventory and natural evaluation results have given the basis for diagnosis and formulating of some directions for landscape protection and planning in the study area. Though the Bielański Forest natural reserve is placed in urban area of the big city - Warsaw capitol of Poland, in its direct and indirect vicinity there are some advantages of existing spatial management and land use as well as real chances of effective improvement possibilities giving more warranty for long-term survival of natural values and landscapes in the reserve and at the same time better environmental conditions for city residents. First of all, the actual land use and management assure medium external ecological connections which can be strengthen by relevant activities. External ecological connections joining the reserve with other naturally important terrains are one of the most important condition for long-term survival. Incidentally, the maintaining and improvement of external ecological corridors is not directly formulated in valid protection plan (Plan ochrony... 2016), what is a defect of this document.

There are existing and should be strengthen such external ecological corridors: (1) corridor along the Vistula River to Młociński Forest and farther to Kampinoska Primeval Forest (Kampinoski National Park) in north-western direction; (2) corridor consisting of the old river bed, allotment gardens and Kępa Potocka Park in south-eastern direction. Both these corridors keep direct contact (being parts of) with the Nature 2000 Area PLB "The Middle Vistula River Valley" comprising the Vistula river and flood terraces between embankments.

In order to strengthen these ecological connections it is recommended:

- unit 19 - indicated to be changed into a forest park with recreation function;

- the waste industrial area - unit 1 - indicated to be afforested or changed into a forest park with extensive recreation function; same goes for the small patches of waste land south of the riparian forest;

- unit 5-recommended for afforestation near the sports grounds;

- the fence built along the north-eastern border of Bielański Forest (fence protecting from collisions and damages through wild animals in Wybrzeże Gdyńskie St.) - should be equipped in one or better two passages for wild animals; such crossing exists there - under bridge overpass of Wybrzeże Gdyńskie St. (unit 6, near border of unit 7), but is badly landscaped and the same is farther to river bed (the need of greenery development and prohibition of cubature objects location). 
Proposed afforestations and/or forest parks would lead to enlargement of forest complexes and creation of more compact forest area closed and along the Vistula river. Such enlargement of forest complexes will make buffer zone for the Bielański Forest nature reserve and strengthen ecological connections mentioned above.

All water elements, especially old river bed of the Vistula river in the eastern part of the study area (units 19 and 15) and local watercourses flowing through Bielański Forest and Linde's Forest (units 12, 4 and 9), should be under special control about water regime and purity including vegetation belts on riverside areas as biological buffers: forest or trees, shrubs, and meadows/ /lawns). Old river bed (without a name; fragment is in the study area - units 15 and 19 - and farther continues to Kępa Potocka Park, in north-eastern direction along Gwiaździsta St.) should be taken under law protection as the ecological site or even natural reserve.

Built-up areas in surroundings of Bielański Forest nature reserve should be enriched in green areas and generally in greenery to enlarge share of biologically active surface from $30 \%$ to even $80-90 \%$ in western and eastern vicinity of Bielański Forest, as it is set up in valid Protection Plan of Bielański Forest Reserve (Plan ochrony... 2016), also enriched in other biologically active elements (ex. green roofs, green walls on buildings).

In all, the study area is a good part of the ecological system of Bielany Municipality in Warsaw. Proposed improvements in spatial planning and management could make it even better.

\section{CONCLUSIONS}

1. The Bielański Forest nature reserve has a major ecological importance for the northern part of Bielany Municipality. It is characterized by very high natural values and its surroundings gives a real chance, especially after some improvements, to keep permanently ecological connections with other external natural refuges.

2. Inventory of spatial management, endangerments and types of landscape, then supported by natural evaluation of the area, gives a good basis for diagnosis and farther for guidelines to landscape shaping and protection in terms of natural values increase.

3. It is worth taking an assessment of surroundings of natural reserves occurring in urban areas in terms of natural values increase and ecological isolation minimizing because of high probability to find some good solutions for landscape planning to enter them into spatial and strategic documents in order to improve "ecologisation" of the whole area including residential terrains.

4. Important directions for landscape planning in surroundings of Bielański Forest natural reserve, in order to minimize ecological isolation, is maintaining and improvement of external ecological connections/corridors: (a) the first one - in direction to Młociński Forest and farther to Kampinoska Primeval Forest, in north-western direction (along and closed to Nature 2000 Area PLB 140004 The Middle Vistula River Valley) waste-up areas and dropped sports areas indicated to be afforested with recreation function; (b) the second one - by including old river bed (lake), allotment gar- 
dens (with possibility to be changed into partly-public park in future) and Kępa Potocka Park - along the Vistula river and flood terraces of the valley (Nature 2000 PLB 140004).

5. Water elements of landscape (the Vistula river, local watercourses and old river bed) should be maintained in good state: proper water regime and purity of water, as well as terrains closed to them covered with vegetation and free of waste. The old river bed (without name) should be taken under legal protection as ecological site or even natural reserve.

\section{REFERENCES}

ALEXANDROWICZ Z., KUĆMIERZ A., URBAN J., OTĘSKA-BUDZYŃ J. 1992: Waloryzacja przyrody nieożywionej obszarów i obiektów chronionych w Polsce [Assessment of inanimate nature of protected areas and objects in Poland]. PIG, Warszawa.

BENEDICT M.A., McMACHON E. 2006: Green Infrastructure. Linking Landscapes and Communities. Island Press, Washington, DC.

BRUNETTA G., VOGHERA A. 2008: Evaluating Landscape for Shared Values: Tools, Principles, and Methods. Landsc. Res. 33 (1): 71-87.

BRYANT M.M. 2006: Urban landscape conservation and the role of ecological greenways at local and metropolitan scales. Landsc. Urban Plan. 76 (1-4): 23-44.

Communication from the Commission to the European Parliament, the Council, the European Economic and Social Committee and the Committee of the Regions: An EU Strategy on adaptation to climate change COM/2013/216.

Communication from the Commission to the European Parliament, the Council, the European Economic and Social Commit- tee and the Committee of Regions: Green Infrastructure (GI) - Enhancing Europe's National Capital. COM/2013/0249.

EMANUEL R., LOCONSOLE A. 2015: Green infrastructure as an adaptation approach to tackling urban overheating in the Glasgow Clyde Valley Region, UK. Landsc. Urban Plan. 138: 71-86. http:// dx.doi.org/10.2016/j.landurbplan.2015.0 2.012

Europejska konwencja krajobrazowa sporządzona we Florencji dnia 20 października 2000 r. [European Landscape Convention (ELC)]. Journal of Laws 2006 No 14, item 98.

GACKA-GRZESIKIEWICZ E., WILAND M., CICHOCKI Z., CIEŚLAK M., ŻARSKA B. 1994: Ochrona przyrody i krajobrazu w planowaniu przestrzennym gmin [Nature and landscape protection in spatial planning]. IOŚ, Warszawa.

GILL S.E., HANDLEY J.F., ENNOS A.R., PAULEIT S. 2007: Adapting Cities for Climate Change: The Role of the Green Infrastructure. Built Environ. 33 (1): 115-133.

HESSBURG P.H., REYNOLDS K.M., SALTER R.B., DICKINSON J.D., GAINES W.L., HARROD R.J. 2013: Landscape evaluation for restoration planning on the Okanogan-Wenatchee National Forest, USA. Sustainability 5 (3): 805-840.

JIM C.Y. 2004: Green-space preservation and allocation for sustainable greening of compact cities. Cities 21 (4): 311-320.

MOSS M.R., NICKLING W.G. 1980: Landscape evaluation in environmental assessment and land use planning. Environ. Manag. 4 (1): 57-72.

MYGA-PIĄTEK U. 2007: Kryteria i metody oceny krajobrazu kulturowego $\mathrm{w}$ procesie planowania przestrzennego na tle obowiązujących procedur prawnych [Criteria and methods for assesing the cultural landscape in the special planning process in the context of applicable legal procedures]. Probl. Ekol. Kraj. 19: 101-111. 
Plan ochrony rezerwatu Las Bielański i obszaru Natura 2000 PLH 140041 „Las Bielański”. Zarządzenie RDOŚ w Warszawie z dnia 22 września 2016 r. Dz.Urz. Woj. Mazowieckiego, poz. 8575 [Protection Plan of Nature Reserve Bielański Forest and the Nature 2000 Area PLH 140041 "Bielański Forest". Regulation of Regional Director for Environmental Protection of September 22, 2016. Official Journal of Mazowieckie Province, position 8575].

SHANAHAN D.F., MILLER C., POSSINGHAM H.P., FULLER R.A. 2011: The influence of patch area and connectivity on avian communities in urban revegetation. Biol. Conserv. 144 (2): 722-729.

SZULCZEWSKA B., KAFTAN J. (Ed.) 1996: Kształtowanie systemu przyrodniczego miasta [Planning of the natural areas system of the city]. IGPiK, Warszawa.

THRELFALL C.G., WILLIAMS N.S.G., HAHS A.K., LIVESLEY S.J. 2016: Approaches to urban vegetation management and the impacts on urban bird and bat assemblages. Landsc. Urban Plan. 153: 28-39.

UNEP 2011: Towards Green Economy. Pathways to Sustainable Development and Poverty Eradication. Green Economy Report. Retrieved form: https:// sustainabledevelopment.un.org/content/ documents/126GER synthesis en.pdf.

YU TING J.K., MAKOTO Y. 2017: Recommendations for Urban Biodiversity Conservation in the Context of Landscape Preference in Singapore. CATE 10 (1): $1-19$.

ZINIA N.J., McSHANE P. 2018: Ecosystem services management: An evaluation of green adaptations for urban development in Dhaka, Bangladesh. Landsc. Urban Plan. 173: 23-32.

ŻARSKA B. 2001: Study of landscape protection - methodics of working out for various areas. Ann. Warsaw Agricult. Univ. - SGGW, Horticult. Landsc. Architect. 22: 111-122.
ŻARSKA B., FORNAL-PIENIAK B., ZARAŚ-JANUSZKIEWICZ E. 2014: Landscape protection and planning. Selected issues. WULS Press, Warsaw.

Streszczenie: Przyrodnicza waloryzacja krajobrazu obszaru zurbanizowanego obejmujacego rezerwat przyrody Las Bielański i jego otoczenie. Warszawa, Polska. Wskazania do ochrony i planowania krajobrazu. Problemy utrzymania pozostałości naturalnych ekosystemów i innych elementów biologicznie aktywnych na obszarach zurbanizowanych, a także zagadnienia związane z ich oceną i diagnozą są bardzo aktualne, łączone najczęściej z koniecznością poprawy warunków środowiskowych i komfortu życia mieszkańców miasta. Kształtowanie systemów przyrodniczych w miastach, zwane aktualnie kształtowaniem zielonej infrastruktury, jako przeciwwagi do terenów zabudowanych wraz z podkreślaniem ważności oceny krajobrazu i racjonalnego planowania przestrzeni, jest przedmiotem wielu badań w ostatnich dekadach. Celem artykułu jest zaprezentowanie metodycznego podejścia do przyrodniczej oceny krajobrazu obszaru zurbanizowanego, obejmującego rezerwat przyrody znajdujący się w granicach dużego miasta wraz z terenami otaczającymi zagospodarowanymi głównie zabudową, oraz w efekcie końcowym sformułowanie wytycznych do ochrony i planowania przestrzennego w aspekcie ochrony wartości przyrodniczych i ekologizacji przestrzeni. Obszar opracowania obejmował rezerwat przyrody „Las Bielański” wraz z jego otoczeniem, o powierzchni $3,85 \mathrm{~km}^{2}$ (w tym powierzchnia rezerwatu $1,3 \mathrm{~km}^{2}$ ). Las Bielański, będący pozostałością Puszczy Mazowieckiej i zlokalizowany na czterech tarasach doliny Wisły, jest jednocześnie obszarem siedliskowym Natura 2000 PLH 140041, który z kolei znajduje się $\mathrm{w}$ bliskim sąsiedztwie ptasiego obszaru Natura 2000 PLB 140004 „Dolina Środkowej Wisły" (fragment wchodził w obszar opracowania). Metodyczne podejście polegało na podziale obszaru badań na jednostki przestrzenno-krajobrazowe, odznaczające się w przybliżeniu jednym typem/podtypem krajobrazu (podział na podstawie dwóch przewodnich kryteriów: rzeźby terenu i pokrycia terenu), dokonaniu inwentaryzacji wybranych elementów krajobrazu $\mathrm{w}$ tych jednostkach z uwzględnieniem zagrożeń, 
następnie waloryzacji przyrodniczej krajobrazu (poszczególnych jednostek) na podstawie zaproponowanego zestawu kryteriów i systemu oceny, a w końcu sformułowaniu wskazań do ochrony i planowania krajobrazu, adresowanych $\mathrm{w}$ większości do terenów otaczających rezerwat (rezerwat ma zatwierdzony plan ochrony w 2016 r., zawierający m.in. działania ochronne i minimalizujące zagrożenia). W waloryzacji zastosowano zbiór dziewięciu parametrów oceny (w tym kryterium: przydatność do pełnienia funkcji korytarza ekologicznego) i dobrano odpowiednio skalę punktową oceny. Ocenie poddano kolejno jednostki przestrzenno-krajobrazowe. Podsumowując przyznane jednostkom punkty, przyjęto cztery kategorie wartości przyrodniczej terenów (od niskich do bardzo wysokich). Sformułowano wytyczne do ochrony i kształtowania krajobrazu, a w szczególności, jako ważne działanie $\mathrm{w}$ aspekcie długoterminowego zachowania przyrodniczych wartości krajobrazu Lasu Bielańskiego wraz z przyległym obszarem Natura 2000 PLB 140004, zaproponowano wzmocnienie i utworzenie zewnętrznych korytarzy ekologicznych. Wskazano również na: utworzenie użytku ekologicznego lub rezerwatu przyrody na terenie starorzecza Wisły, zmianę funkcji terenów zaniedbanych i poprzemysłowych na lasy/parki leśne $\mathrm{z}$ funkcją rekreacyjną i/lub sportową, zwiększenie udziału powierzchni biologicznie czynnych i wzbogacenie terenów zabudowanych $\mathrm{w}$ inne elementy aktywnie biologiczne, a także przystosowanie przynajmniej jednego z istniejących prześwitów pod trasą szybkiego ruchu jako przejścia dla dzikich zwierząt (w kierunku do i od koryta Wisły).

Stowa kluczowe: planowanie krajobrazu, przyrodnicza waloryzacja krajobrazu, pozostałości naturalnych ekosystemów, obszar zurbanizowany, system przyrodniczy obszaru

MS received 10.04.2018

MS accepted 15.07.2018

\section{Authors' address:}

Beata Fornal-Pieniak

Katedra Ochrony Środowiska

Wydział Ogrodnictwa, Biotechnologii i Architektury Krajobrazu

Szkoła Główna Gospodarstwa Wiejskiego

w Warszawie

ul. Nowoursynowska 166, 02-767 Warszawa

Poland

e-mail: beata_fornal_pieniak@sggw.pl 